\title{
TESTOSTERONE PROPIONATE DURING GESTATION IN THE RABBIT: EFFECT ON SUBSEQUENT MATERNAL BEHAVIOUR
}

\author{
G. B. FULLER, ${ }^{*}$ M. X. ZARROW, $†$ C. O. ANDERSON $\ddagger$ \\ AND V. H. DENENBERG $\dagger$ \\ Departments of Biological Sciences and Psychology, Purdue University, \\ Lafayette, Indiana 47907, U.S.A.
}

(Received 18th November 1969)

\begin{abstract}
Summary. Groups of pregnant, Purdue, Dutch-belted rabbits were injected with three levels of testosterone propionate from Days 17 to 29 of gestation. Treatment periods and the daily amount of testosterone injected were: Days 17 to $21,5 \mathrm{mg}$; Days 22 to $25,2.5 \mathrm{mg}$; Days 27 to $29,2.5$ or $1 \mathrm{mg}$. Testosterone treatment for the complete schedule (i.e. Days 17 to 29) resulted in significant suppression of maternal-nestbuilding behaviour, failure to rear litters, increased incidence of abortion or resorption and presence of scattering, cannibalism or failure to nurse. Only the complete treatment schedule significantly inhibited maternal nest building while lack of litter care could be produced by treatment during Days 17 to 25 or Days 27 to 29 . In addition, treatment during Days 17 to 25 produced a significant increase in abortion and/or resorption. Results are discussed in terms of the interaction between testosterone and normal endocrine requirements for maternal behaviour.
\end{abstract}

\section{INTRODUCTION}

Many experiments have been designed to investigate the influence of sex steroids on the central nervous system. Administration of the gonadal hormones before birth, after birth, or to adult rats (Fisher, 1956; Revesez, Kernaghan \& Bindra, 1962; Harris \& Levine, 1965; Feder, 1967), mice (Barraclough \& Leathem, 1954), guinea-pigs (Phoenix, Goy, Gerall \& Young, 1959; Diamond, 1966; Goy, Phoenix \& Meidinger, 1967) and rabbits (Hu \& Frazier, 1939; Campbell, 1964, 1965; Palka \& Sawyer, 1966) has induced both somatic and behavioural alterations. While administration of steroids to adults is considered to have an 'activating' function, exposure of the foetal or neonatal animal to exogenous steroids produces permanent 'organizing' changes in adult sexual behaviour (Beach, 1948; Young, Goy \& Phoenix, 1964).

Present addresses: * Department of Animal Sciences, University of New Hampshire, Durham, New Hampshire. † Department of Biobehavioral Sciences, University of Connecticut, Storrs, Connecticut 06268. $\ddagger$ Tulane University, Delta Regional Primate Center, Covington, Louisiana 70433. 
The administration of exogenous steroids to mature rabbits can produce changes in behaviour analogous to those produced in other animals. $\mathrm{Hu} \&$ Frazier (1939) reported male-like behaviour in mature female rabbits after treatment with testosterone propionate for several days. Implantation of testosterone into the ventromedial pre-mammillary region of the hypothalamus also resulted in an intense oestrous behaviour of mature ovariectomized female rabbits (Palka \& Sawyer, 1966). Similarly, male sexual behaviour has been easily induced in female rats and guinea-pigs following injections of testosterone (Ball, 1940; Young, 1961; Diamond \& Young, 1963).

In spite of numerous reports concerning the effects of gonadal hormones on mating behaviour, only a few studies have examined the subsequent maternal behaviour of those females which became pregnant. Androgens have been administered to pregnant guinea-pigs (Phoenix et al., 1959; Diamond, 1966; Goy et al., 1967) and rats (Revesez et al., 1962) without apparently disturbing maternal behaviour at or after parturition, although a higher percentage of resorptions or abortions occurred than is normally encountered. Campbell (1964) reported an alteration in maternal behaviour in the rabbit following injection of testosterone propionate from Day 17 to Day 29 of gestation. All components of maternal behaviour, including nest building and care of the young, were disrupted.

The present study was designed to examine the effects of testosterone propionate injections in the pregnant rabbit on maternal behaviour and to investigate the possibility of distinguishing between the effects of the hormones on maternal nest building and other components of maternal behaviour. A maternal nest is defined as one composed of straw and hair pulled by the doe from her own body (Ross, Sawin, Zarrow \& Denenberg, 1963). A maternal nest should be distinguished from a straw nest, since the latter may be present independent of any other correlates of maternal behaviour.

\section{MATERIALS AND METHODS}

Purdue Dutch-belted females, from 4 to 5 months of age, were maintained in standard cages until mated. Pregnancy was confirmed by palpation 10 to 12 days after mating. At this time, the females were transferred to individual maternity cages and provided with nesting material and a wooden nest box measuring $11 \times 11 \times 22$ in. which was divided into two compartments by a 3-in. partition (Zarrow, Sawin, Ross, Denenberg, Crary, Wilson \& Farooq, 1961). The animals were housed under uniform conditions of temperature $\left(70\right.$ to $\left.72^{\circ} \mathrm{F}\right)$ and humidity $(50 \%)$ while maintained under an automatically controlled light schedule of $13 \mathrm{hr}$ ( 07.00 to 20.00 hours). Unrestricted supplies of pelleted rabbit food, hay and water were provided.

Testosterone propionate was dissolved in peanut oil and injected subcutaneously in the dorsal neck region. The seven treatment regimens are presented in Table 1. The animals were observed shortly after parturition for number of live young delivered and incidence of cannibalism. Litters were checked daily during lactation for dead young and general observations were made on maternal care of the young. 


\section{RESULTS}

The results presented in Table 1 demonstrate an effect of testosterone on maternal nest building. The chi-square value for all groups $\left(\chi^{2}=18.72\right.$; d.f. $=6 ; P<0.005)$ reflects the disparity between the percentage of controls (Group 1) which built maternal nests $(97.2 \%)$ and those in Group 2 which received the full testosterone treatment $(71 \cdot 4 \%)$. The difference between these two groups was significant $\left(\chi^{2}\right.$ corrected for continuity $=10.85$; d.f. $=1$; $P<0.001)$. No other group differed significantly from the control group. It therefore appears that testosterone during the full 12-day treatment schedule is necessary to produce a significant influence on maternal nest-building behaviour.

TABLE 1

THE EFFEGT OF TESTOSTERONE PROPIONATE DURING GESTATION ON MATERNAL BEHAVIOUR OF DUTCH-BELTED FEMALES

\begin{tabular}{|c|c|c|c|c|c|c|}
\hline \multirow[b]{2}{*}{ Group } & \multirow{2}{*}{\multicolumn{2}{|c|}{\begin{tabular}{lc}
\multicolumn{2}{c}{ Treatment } \\
Amount & Day of \\
injected & pregnancy
\end{tabular}}} & \multirow[b]{2}{*}{$\begin{array}{l}\text { No. of } \\
\text { animals }\end{array}$} & \multicolumn{3}{|c|}{ Rabbits $(\%)$} \\
\hline & & & & $\begin{array}{l}\text { Nest built, } \\
\text { litter } \\
\text { reared }\end{array}$ & $\begin{array}{l}\text { Nest built, } \\
\quad \text { litter } \\
\text { not reared }\end{array}$ & $\begin{array}{l}\text { Nest not built, } \uparrow \\
\quad \text { litter } \\
\text { not reared }\end{array}$ \\
\hline 1 & & Controls & $10^{*}$ & 100 & 0.0 & 0.0 \\
\hline 2 & $\begin{array}{l}5.0 \mathrm{mg} \\
2.5 \mathrm{mg} \\
1.0 \mathrm{mg}\end{array}$ & $\begin{array}{l}\text { Days } 17 \text { to } 21 \\
\text { Days } 22 \text { to } 25 \\
\text { Days } 27 \text { to } 29\end{array}$ & 14 & $21 \cdot 4$ & $50 \cdot 0$ & $28 \cdot 6$ \\
\hline 3 & $\begin{array}{l}5.0 \mathrm{mg} \\
2.5 \mathrm{mg}\end{array}$ & $\begin{array}{l}\text { Days } 17 \text { to } 21 \\
\text { Days } 22 \text { to } 25\end{array}$ & 10 & $40 \cdot 0$ & $60 \cdot 0$ & 0.0 \\
\hline 4 & $1.0 \mathrm{mg}$ & Days 27 to 29 & 12 & $41 \cdot 7$ & $41 \cdot 7$ & $16 \cdot 6$ \\
\hline 5 & $2.5 \mathrm{mg}$ & Days 27 to 29 & 15 & $71 \cdot 4$ & $14 \cdot 3$ & $14 \cdot 3$ \\
\hline 6 & $5.0 \mathrm{mg}$ & Days 17 to 21 & 8 & $100 \cdot 0$ & 0.0 & 0.0 \\
\hline 7 & $2.5 \mathrm{mg}$ & Days 22 to 25 & 6 & 83.5 & $16 \cdot 7$ & 0.0 \\
\hline
\end{tabular}

* Cumulative colony controls for a 10-year period including ten controls from the present study consist of 108 rabbits of which $93.5 \%$ built nests, $3.7 \%$ built nests but failed to rear litters and $2.8 \%$ failed to build nests or rear litters.

$\uparrow$ No rabbits reared their young if they failed to build a maternal nest.

Testosterone propionate administered during gestation also affected care of the injected female's litter $\left(\chi^{2}=54.18 ;\right.$ d.f. $\left.=6 ; P<0.001\right)$. While the majority of untreated females $(93.5 \%)$ reared their litters to weaning, females in Groups 2, 3, 4 and 5 treated with testosterone during Days 17 to $29(21.4 \%)$, Days 17 to $25(40.0 \%)$ or Days 27 to $29(15 / 26=57.7 \%$; includes both dose levels for the same treatment period) showed significantly depressed litter care $(P<0.001$ for each group compared to controls). Treatment during Days 17 to $21(100 \%)$ or Days 22 to $25(83.3 \%)$ alone had no significant effect.

Data concerning abortion and resorption for normal, untreated rabbits were obtained from the Purdue Dutch-belted colony females observed during the period of January 1967 to April 1969. Sixty-six of these animals were studied during their first gestation and only two resorbed (3.0\%), while none aborted. Using these as control data, overall chi-square indicates a significant difference among the groups $\left(\chi^{2}=25.00 ;\right.$ d.f. $\left.=6 ; P<0.001\right)$. This result is apparently 
due to high abortion or resorption in females treated during Days 17 to 29 $(36.4 \%)$ and Days 17 to $25(33.3 \%)$ of gestation $\left(\chi^{2}\right.$ corrected for continuity $=$ 15.04 and 10.64, respectively, d.f. $=1, P<0.01)$.

In accordance with previous results, all rabbits failed to rear their young if a maternal nest was not built (Zarrow, Farooq, Denenberg, Sawin \& Ross, 1963).

\section{DISCUSSION}

Treatment with testosterone propionate during the second half of gestation (Days 17 to 29 less Day 26) significantly inhibited maternal nest building and care of the litter through weaning, and increased the likelihood that the female would abort or resorb the young. Inhibition of maternal nest building appeared to require the full 12 days of the treatment since no other portion of the treatment time, including the first 9 days, was sufficient to inhibit this behaviour. That extended testosterone treatment is required is not too surprising since it has been shown that nest building in the rabbit following ovariectomy during pregnancy required 15 to 17 days of gestation (Zarrow, Farooq \& Denenberg, 1962).

The attempt to determine that portion of the full treatment period which was directly related to maternal care revealed the independent importance of Days 17 to 25 and Days 27 to 29. Treatment during either period disrupted maternal care. The majority of females that failed to care for their young delivered them on the cage floor and either cannibalized or mutilated them within $24 \mathrm{hr}$ of birth. In some instances, they were abandoned or not allowed to suckle even though a normal delivery utilizing the maternal nest had occurred. It was evident that death of the young was not due to a lactation problem as large quantities of milk were present in the mammary glands at post mortem examination. Since the presence of the maternal nest did not change the statistical significance of these results, it is unlikely that the young died from being chilled. Three factors seem to be involved: the active cannibalism of young, the failure to deliver young in the nest box (scattering) and the failure to nurse young born into the nest box. Cannibalism would seem to be an 'activated' behaviour, while scattering and failure to nurse young indicate the absence of activation. It may very well be that the presence of testosterone propionate during Days 17 to 25 or Days 27 to 29 of gestation activates neural components important to cannibalistic behaviour or prevents ovarian steroids from inhibiting them. At the same time, it is possible that scattering and failure to nurse are the result of testosterone preventing the activation of important inhibitory neural target structures.

The present data indicate that maternal nest building may be separated from other maternal behaviour patterns, notably care and rearing of the young. For those does which did build maternal nests, treatment for the entire period (Days 17 to 29) resulted in a failure in $50 \%$ of the rabbits to rear their young as compared to $0.0 \%$ for the controls. Comparable results were obtained with the 17 to 25 days of treatment and with $1 \mathrm{mg}$ of testosterone propionate for Days 27 to 29 . Treatment with a higher dose $(2.5 \mathrm{mg})$ failed to give comparable 
results and no explanation can be offered at this time. Thus, while significant inhibition of the maternal nest building behaviour pattern required the full treatment period with testosterone propionate, shorter treatment periods were sufficient to inhibit the behaviour pattern for care and rearing of the young.

In contrast to our data, Campbell (1964) found that New Zealand females given the full treatment schedule used by us showed complete inhibition of maternal nest building as well as total lack of care of the young. Although we found the same behaviour in identically treated Dutch-belted females, the incidence was not nearly so great. Such differences may be due to the small number of subjects used by Campbell $(N=3)$, environmental factors and the different strains used. Strain differences in the incidence of maternal nest building after ovariectomy of the pregnant doe have been reported for the Dutch-belted and the Grey chinchilla (Zarrow, Denenberg \& Kalberer, 1965).

\section{ACKNOWLEDGMENT}

This research was aided in part by Program Project Grant HD-04639 from the National Institute of Child Health and Human Development, National Institutes of Health.

\section{REFERENCES}

BaLI, J. (1940) The effect of testosterone on the sexual behaviour of female rats. F. comp. Psychol. 29, 151.

Barraclough, C. A. \& Leathem, J. H. (1954) Infertility induced in mice by a single injection of testosterone propionate. Proc. Soc. exp. Biol. Med. 85, 673.

BeACH, F. A. (1948) Hormones and behaviour. Hoeber, New York.

CAMPBelL, H. J. (1964) Androgen-induced reversal of parental behaviour in the female rabbit. Nature, Lond. 204, 809.

CAMPBELL, H. J. (1965) The effect of neonatal injections of hormones on sexual behaviour and reproduction in the rabbit. F. Physiol., Lond. 181, 568.

Diamond, M. (1966) Progestagen inhibition of normal sexual behaviour in the male guinea pig. Nature, Lond. 209, 1322.

Diamond, M. \& Young, W. C. (1963) Differential responsiveness of pregnant and nonpregnant guinea pigs to the masculinizing action of testosterone propionate. Endocrinology, 72, 429.

FEDER, H. H. (1967) Specificity of testosterone and estradiol in the differentiating neonatal rat. Anat. Rec. 157, 79.

Fisher, A. E. (1956) Maternal and sexual behaviour induced by intracranial chemical stimulation. Science, N.Y. 124, 228.

Goy, R. W., Phoenix, C. H. \& Meidinger, R. (1967) Postnatal development of sensitivity to estrogen and androgen in male, female and pseudohermaphroditic guinea pigs. Anat. Rec. 157, 87.

Harris, G. W. \& Levine, S. (1965) Sexual differentiation of the brain and its experimental control. 7. Physiol., Lond. 181, 379.

Hu, C. K. \& Frazier, G. N. (1939) Masculinization of the adult female rabbit following injection of testosterone propionate. Proc. Soc. exp. Biol. Med. 42, 820.

PalKa, T. S. \& SAWYER, C. H. (1966) Induction of estrous behaviour in rabbits by hypothalamic implants of testosterone. Am. J. Physiol. 211, 225.

Phoenix, C. H., Goy, R. W., Gerall, A. A. \& Young, W. C. (1959) Organizing action of prenatally administered testosterone propionate on the tissues mediating mating behaviour in the female guinea pigs. Endocrinology, 65, 369 .

Revesez, C., Kernaghan, D. \& Bindra, D. (1962) Sexual drive of female rats 'masculinized' by testosterone during gestation. $\mathcal{F}$. Endocr. 25, 549 .

Ross, S., Sawin, P. B., Zarrow, M. X. \& Denenberg, V. H. (1963) Maternal behaviour in the rabbit. In: Maternal Behaviour in Mammals, 3rd edn, p. 94. Ed. H. L. Rheingold. Wiley, New York.

Young, W. C. (1961) The hormones and mating behavior. In: Sex and Internal Secretions, 3rd edn, p. 1173. Ed. W. C. Young. Williams \& Wilkins, Baltimore. 
Young, W. C., Goy, R. W. \& Phoentx, C. N. (1964) Hormones and sexual behavior. Science, N.Y. 143, 212.

Zarrow, M. X., Denengerg, V. H. \& Kalberer, W. D. (1965) Strain differences in the endocrine bases of maternal nest building in the rabbit. F. Reprod. Fert. 10, 397.

Zarrow, M. X., FARooQ, A. \& Denenberg, V. H. (1962) Maternal behaviour in the rabbit: critical period for nest building following castration during pregnancy. Proc. Soc. exp. Biol. Med. 111, 537.

Zarrow, M. X., FarooQ, A., Denengerg, V. H., SAwin, P. B. \& Ross, S. (1963) Maternal behaviour in the rabbit: endocrine control of maternal-nest building. F. Reprod. Fert. 6, 375.

Zarrow, M. X., Sawin, P. B., Ross, S., Denenberg, V. H., Crary, D. D., Wilson, E. D. \& Farooe, A. (1961) Maternal behaviour in the rabbit: evidence for an endocrine basis of maternal-nest building and additional data for maternal-nest building in the Dutch-belted race. F. Reprod. Fert. 2, 152. 